\title{
Alternative Substrates in the Development of Little Beak Pepper Sprouts
}

\author{
${ }^{1}$ Francielli Geremia, ${ }^{2}$ Rodrigo Hossel, ${ }^{3}$ Alberto Ricardo Stefeni, ${ }^{4}$ Rayanah Stival Svidzinski, ${ }^{5}$ Fernando Luiz \\ Schneider, ${ }^{6}$ Claudia Manteli, ${ }^{7}$ Lucheli Sirtoli Corá
}

${ }^{1}$ Agronomist engineer, Teaching Union of the Southwest of Paraná (Unisep), Dois Vizinhos, PR, 85660-000, Brazil.

${ }^{2}$ Agronomist engineer, Union of the Southwest of Paraná (Unisep), Dois Vizinhos, PR, 85660-000, Brazil.

${ }^{3}$ Department of Agronomy, Federal Technological University of Paraná (UTFPR), Pato Branco, PR, 85503-390, Brazil.

${ }^{4}$ Department of Agroecosystem, Federal Technological University of Paraná (UTFPR), Dois Vizinhos, PR, 85660-000, Brazil.

${ }^{5}$ Department of Agronomy, Federal Technological University of Paraná (UTFPR), Pato Branco, PR, 85503-390, Brazil.

${ }^{6}$ Agronomist Engineer, Teaching Union of the Southwest of Paraná (Unisep), Dois Vizinhos, PR, 85660-000, Brazil.

${ }^{7}$ Agronomist engineer, Teaching Union of the Southwest of Paraná (Unisep), Dois Vizinhos, PR, 85660-000, Brazil.

Correspondence Author: Alberto Ricardo Stefeni, Department of Agronomy, Federal Technological University of Paraná (UTFPR), Pato Branco, PR, 85503390, Brazil.

E-mail: Albertostefeni@yahoo.com.br

Received date: 18 May 2019, Accepted date: 26 June 2019, Online date: 29 June 2019

Copyright: (C) 2019 Francielli Geremia et al, This is an open-access article distributed under the terms of the Creative Commons Attribution License, which permits unrestricted use, distribution, and reproduction in any medium, provided the original author and source are credited.

\begin{abstract}
As it belongs to the solanaceae family, the little beak pepper has been triggering the interest of the food industries in Brazil. One of the main characteristics of this plant is its capability of adaptation to different soils and climates. Alas, in order to obtain quality yielded sprouts, the use of a proper substrate is a determining factor. The evaluation of alternative substrates in the developments of little beak pepper sprouts (Capsicum Chinese) is the goal of this article. This experiment has been realized at Casa de Vegetação, Linha Bonifácio community, city of Planalto - PR. The esperiment is qualitative and the delimitation used was completely randomized (DIC), concerning eight treatments and four repetitions of ten plants each. For obtaining the substrates, sub products on the 1:1:1 (v/v) proportion have been used, the ones that consisted in T1 - pine bark + poultry manure; T2 - pine bark + bovine manure; T3 - sawdust + poultry manure; T4 - sawdust + bovine manure; T5 - cane bagasse + poultry manure; T6 cane bagasse + bovine manure; $\mathrm{T} 7$ - cane bagasse + bovine manure + poultry manure + sawdust and T8 - Witness (Fertile humus). The experiment's evaluation was conducted 60 days after the emergency. The variables evaluated were the size of the aerospace, root length, diameter of the plant's colon, number of leafs per plant, green mass of the aerial space, root's green mass and the plant's total green mass. The pine crust + cattle manure substrate presented a more satisfactory performance in all the analyzed variables. Thus, it becomes the more recommended substrate to obtaining little beak pepper sprouts (Capsicum Chinese) in these conditions. However, the other components of the substrate also present good efficiency in which they can present satisfactory yields in order to obtain more specific results that may present satisfactory yields evaluated in this article.
\end{abstract}

Keywords: Solanaceae, Capscium Chinese, sprouts production

\section{INTRODUCTION}

Pepper is also known as an aromatic spice. They are plants which produce fruits cooking as spices which generally present spicy flavor. In addition to the consumption in nature, pepper fruits are very much required by the food and pharma industries (EMBRAPA HORTALIÇAS, 2012).

The little beak pepper, in special, presents a vast use in the aesthetic complement of restaurant dishes besides presenting beneficial properties. The single factor that draw one's attention is the close inexistence of pungency in this species so much so that it has pleased a wide range of people of all ages (DANTAS, 2015).

In this context, an arising interest of industries for plants that present anti-oxidant active principles is taking place by which they can be used for food conservancy. Being a natural source of anti-oxidants is only another feature of the Capsicum gender peppers. They are also rich in Vitamins E, C and carotenoids, the latter being a great protection against carcinogenic components and slowing early aging. (COSTA et al., 2009; PINTO, 2013). 
Citation: Francielli Geremia et al., Alternative Substrates in the Development of Little Beak Pepper Sprouts. Australian Journal of Basic and Applied Sciences, 13(6): 51-61. DOI: 10.22587/ajbas.2019.13.6.6

Although the species present an excellent capacity of adaptation to different soils, the substrate utilized in the production is a determining factor for obtaining the best quality sprouts.

The substrate can be considered one of the main components in the production of high-quality plants, thus they must present some important characteristics as is the case of acquisition and transportation availability, lack of pathogens, necessary amount of essential nutrients, adequate $\mathrm{pH}$, texture and structure (SILVA et al., 2001).

Another important factor to take into account concerning substrates, is availability of those to the sprouts producers, in an uniform composition, presenting low density, porosity, water retention capability and cation exchange (CTC), not to mention that is also has to be free of plagues and pathogenic organisms but also any type of weeds (Cunha et al. 2005).

The article has its purpose to evaluate the use of alternative substrates in the development of the little beak pepper (Capsicum Chinese).

\section{MATERIAL AND METHODS}

The experiment was conducted in a greenhouse, with an average temperature of $25^{\circ} \mathrm{C} \pm 1$ and relative humidity of $90 \%$. This structure is located on the property of the Hossel family, located in the Bonifácio Line community, in the municipality of Planalto, state of Paraná.

The local climatic classification, according to Köppen-Geiger is Cfa - Subtropical climate; mean temperature in the coldest month below $18^{\circ} \mathrm{C}$ (mesothermic) and average temperature in the warmer month above $22^{\circ} \mathrm{C}$, with no defined dry season, with hot summers, infrequent frost and tendency of rainfall concentration in the summer months (ALVARES et al., 2012).

The experiment was qualitative, and the design was completely randomized (ICD), with eight treatments with four replicates of ten plants each.

In order to obtain the substrates, 1: 1: $1(\mathrm{v} / \mathrm{v})$ by-products were used, consisting of T1 - pine bark + poultry manure; T2 pine bark + bovine manure; T3 - sawdust + poultry manure; T4 - sawdust + bovine manure; T5 - cane bagasse + poultry manure; T6 - cane bagasse + bovine manure; T7 - cane bagasse + cattle manure + poultry manure + sawdust and T8 - Witness (Fertile Humus). After obtaining the substrates, samples of each substrate were collected, characterizing them chemically as potassium $(\mathrm{K})$, phosphorus $(\mathrm{P})$, copper $(\mathrm{Cu})$, iron $(\mathrm{Fe})$, zinc $(\mathrm{Zn})$, manganese $(\mathrm{Mn})$, aluminum $(\mathrm{Al})$, calcium $(\mathrm{Ca})$, magnesium $(\mathrm{Mg})$ and organic matter (figures 1,2,3,4,5,6,7 and 8).

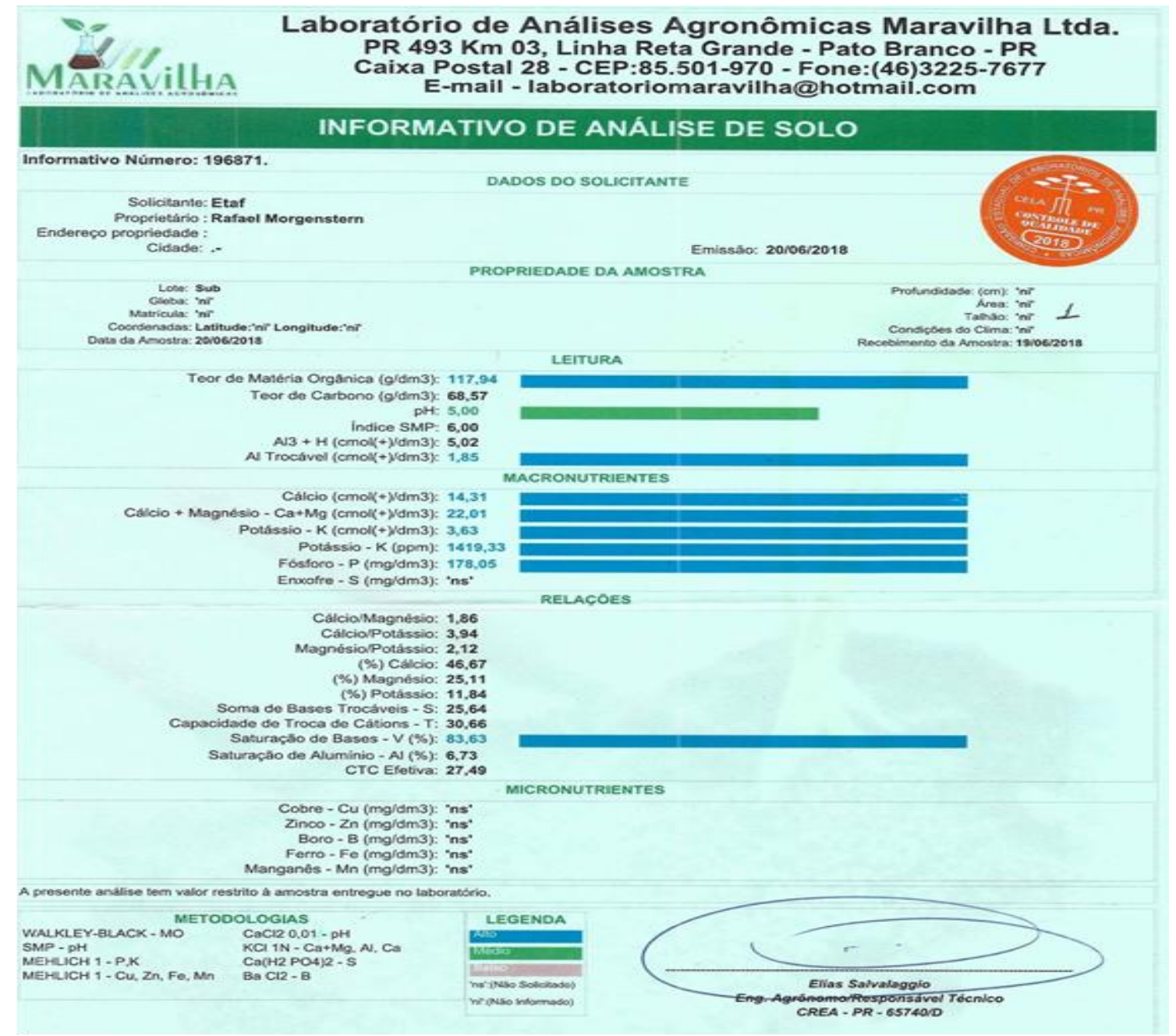

Figure 01 - Analysis of the chemical composition of the substrate based on pinus bark + poultry manure, 2018. 
Source: The author

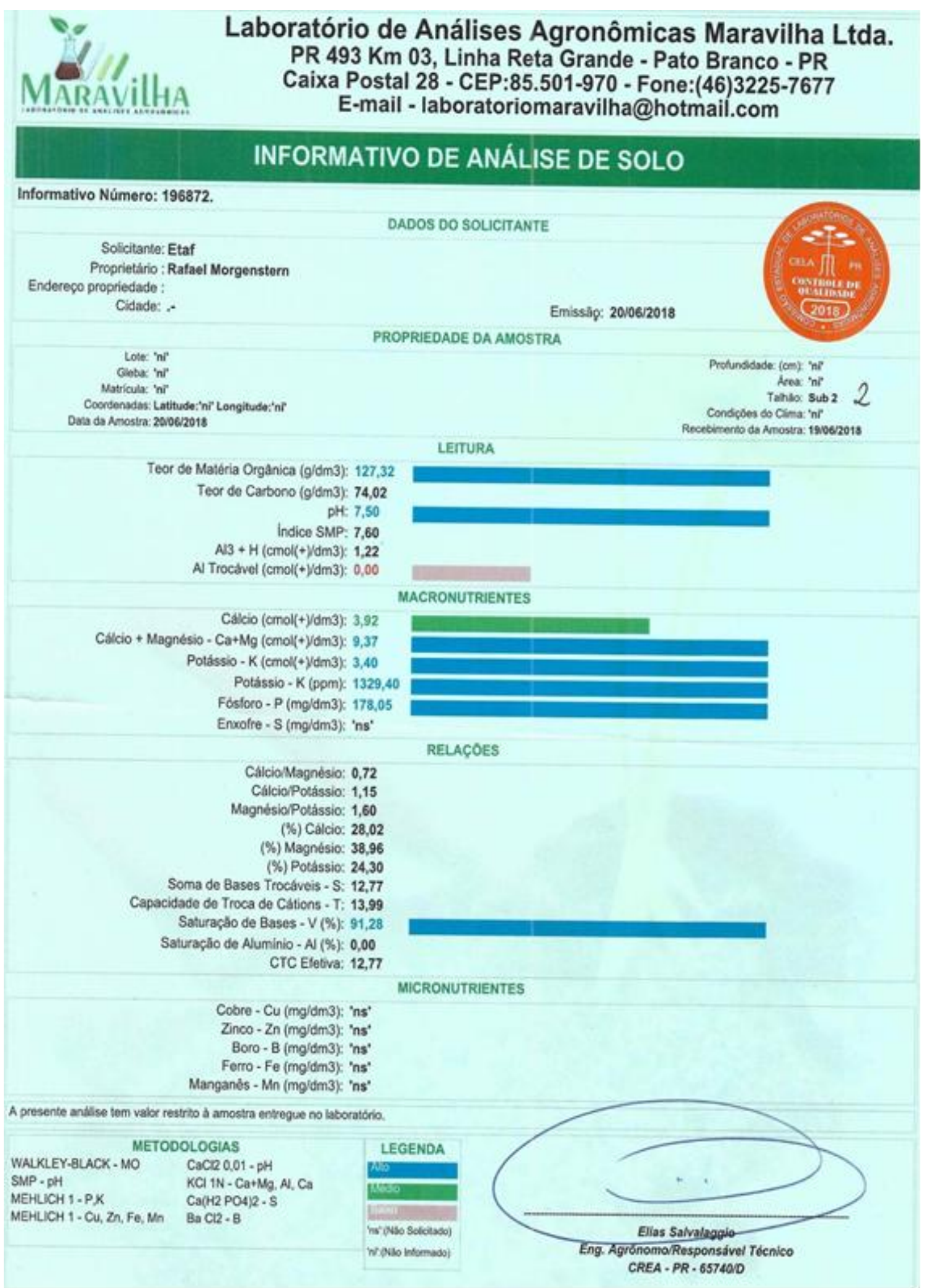

Figure 02 - Analysis of the chemical composition of the substrate based on pinus bark + bovine manure, 2018.

Source: The author 


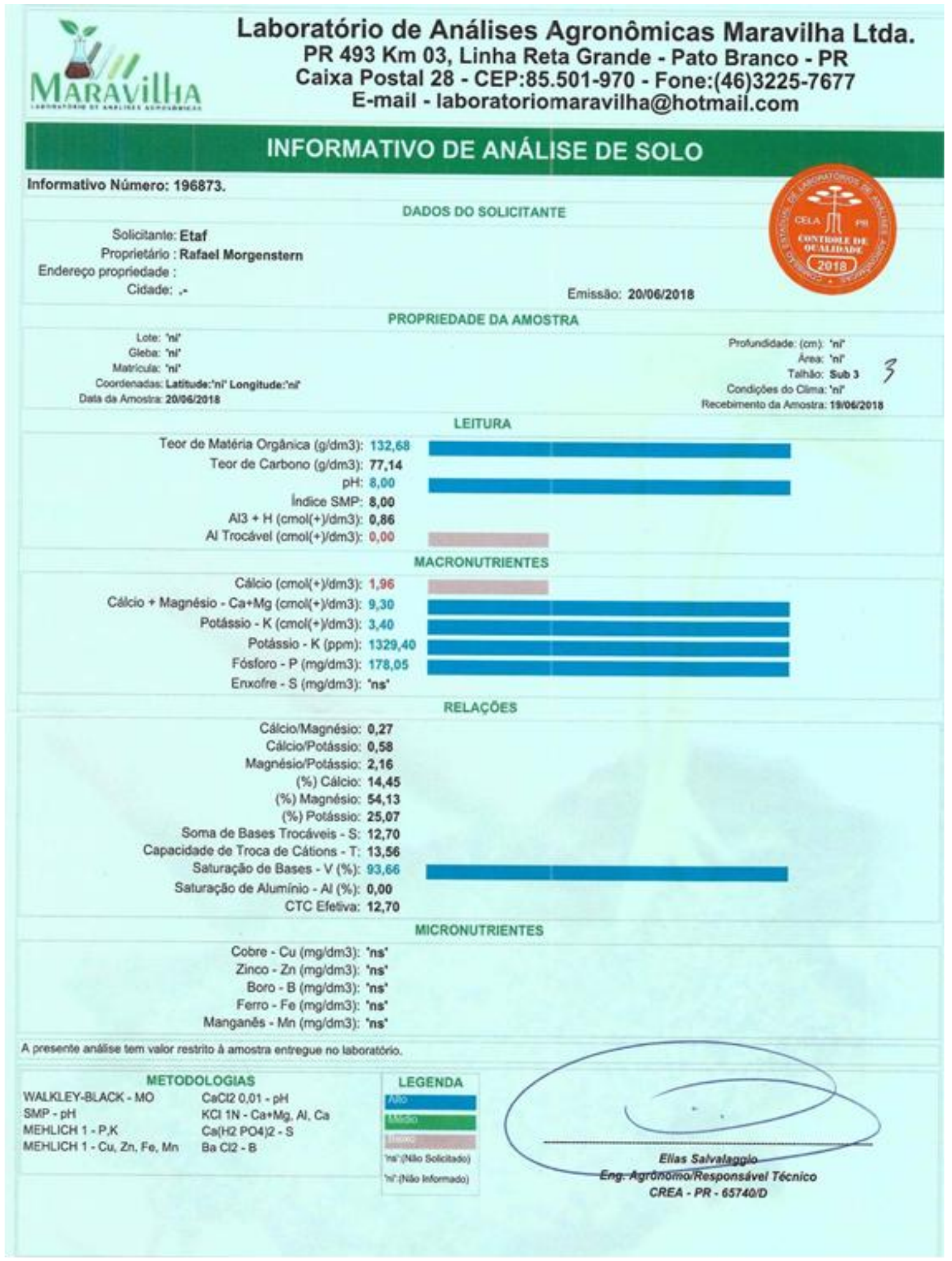

Figure 03 - Analysis of the chemical composition of the substrate based on sawdust + poultry manure, 2018. Source: The author 


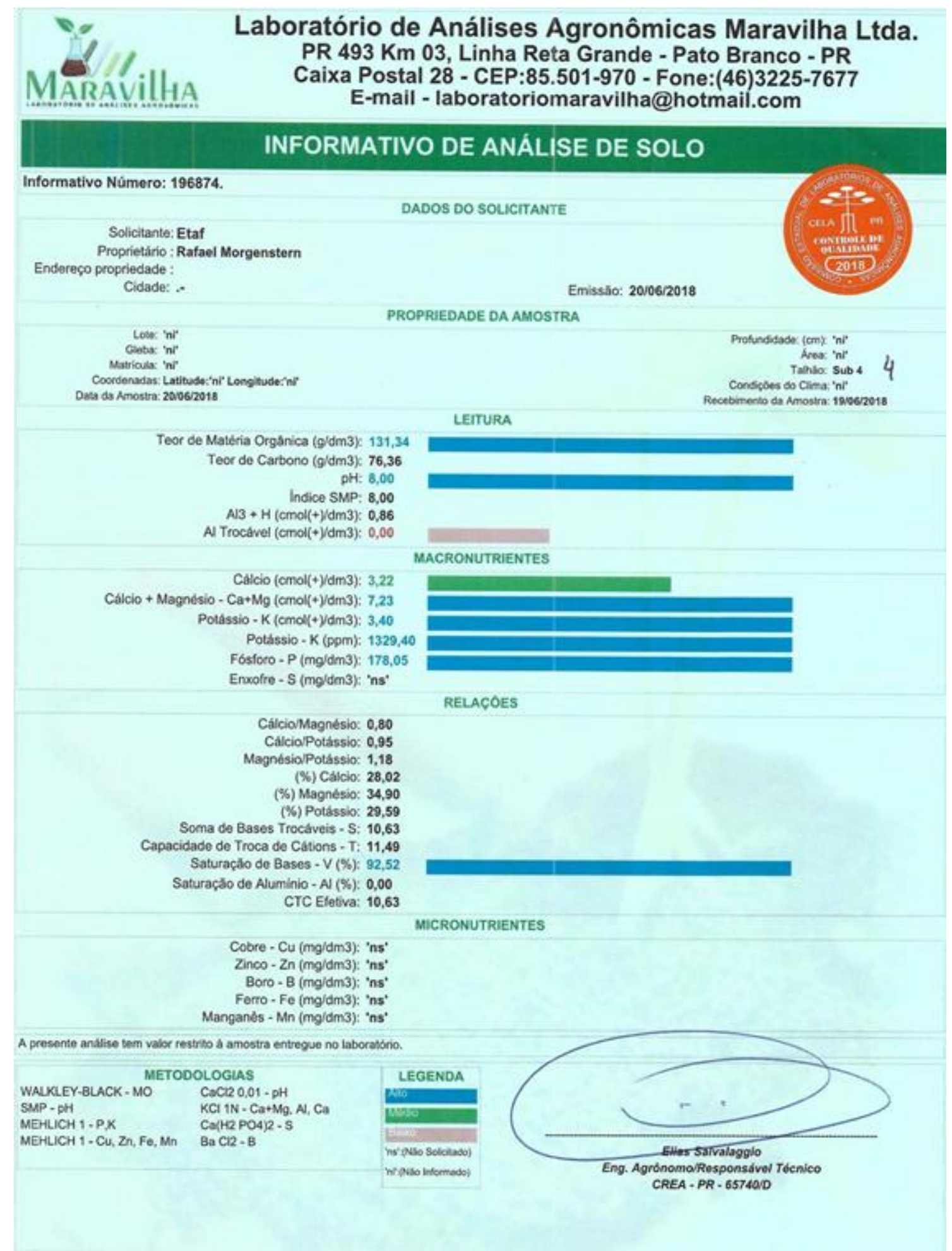

Figure 04 - Analysis of the chemical composition of the substrate based on sawdust + bovine manure, 2018. Source: The author 


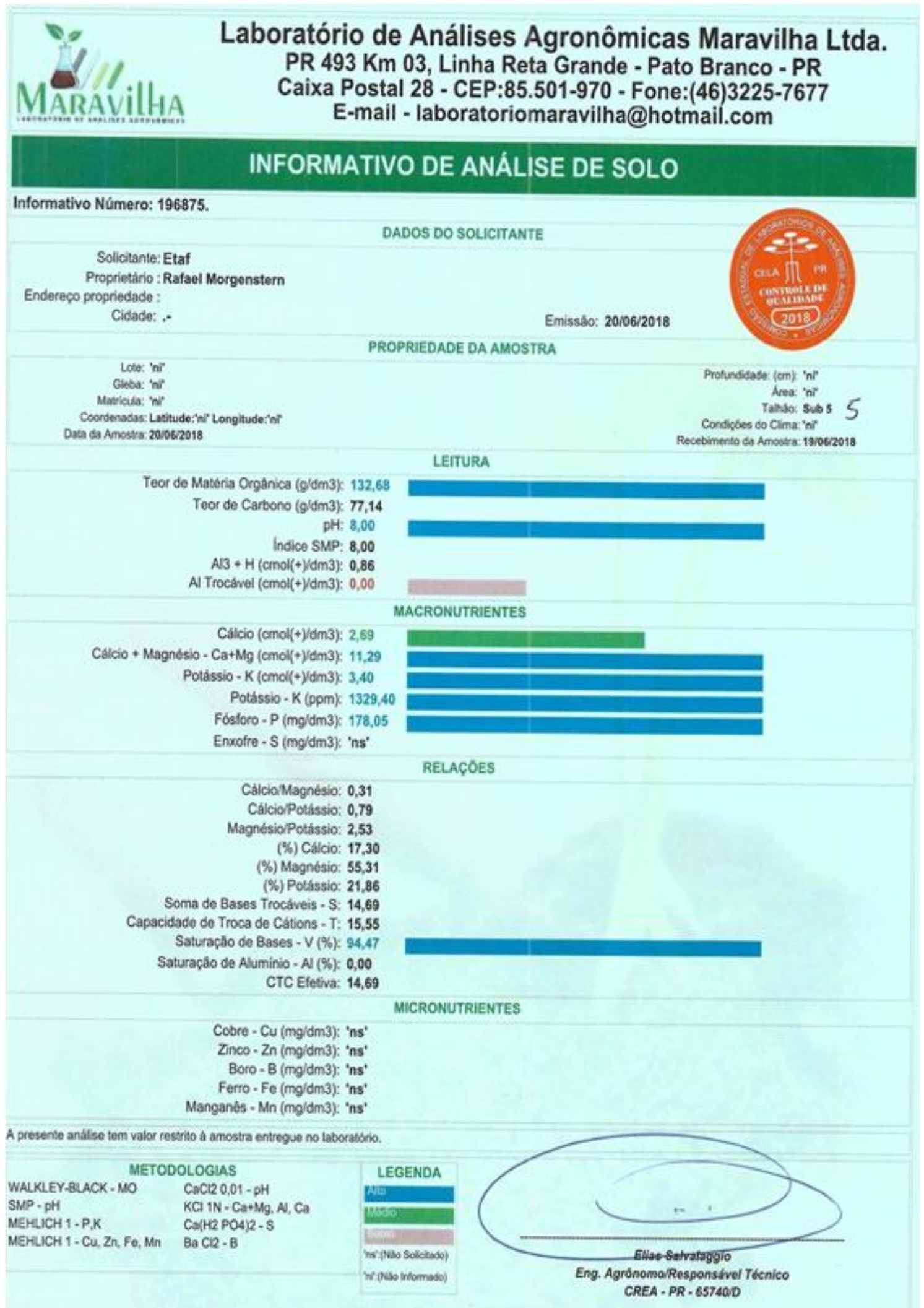

Figure 05 - Analysis of the chemical composition of the substrate based on cane bagasse + poultry manure, 2018. Source: The author 


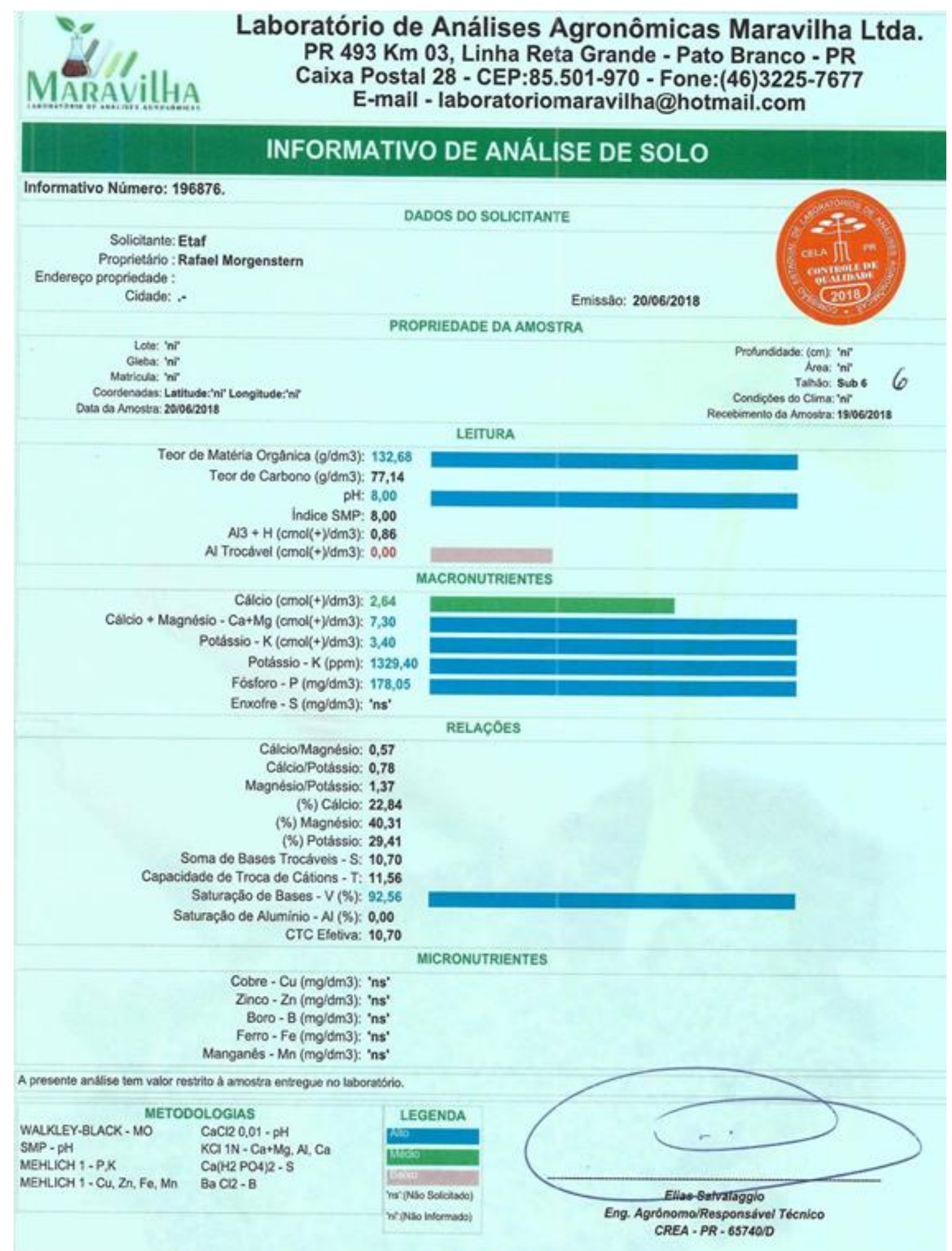

Figure 06 - Analysis of the chemical composition of the substrate based on cane bagasse + bovine manure, 2018. Source: The author 


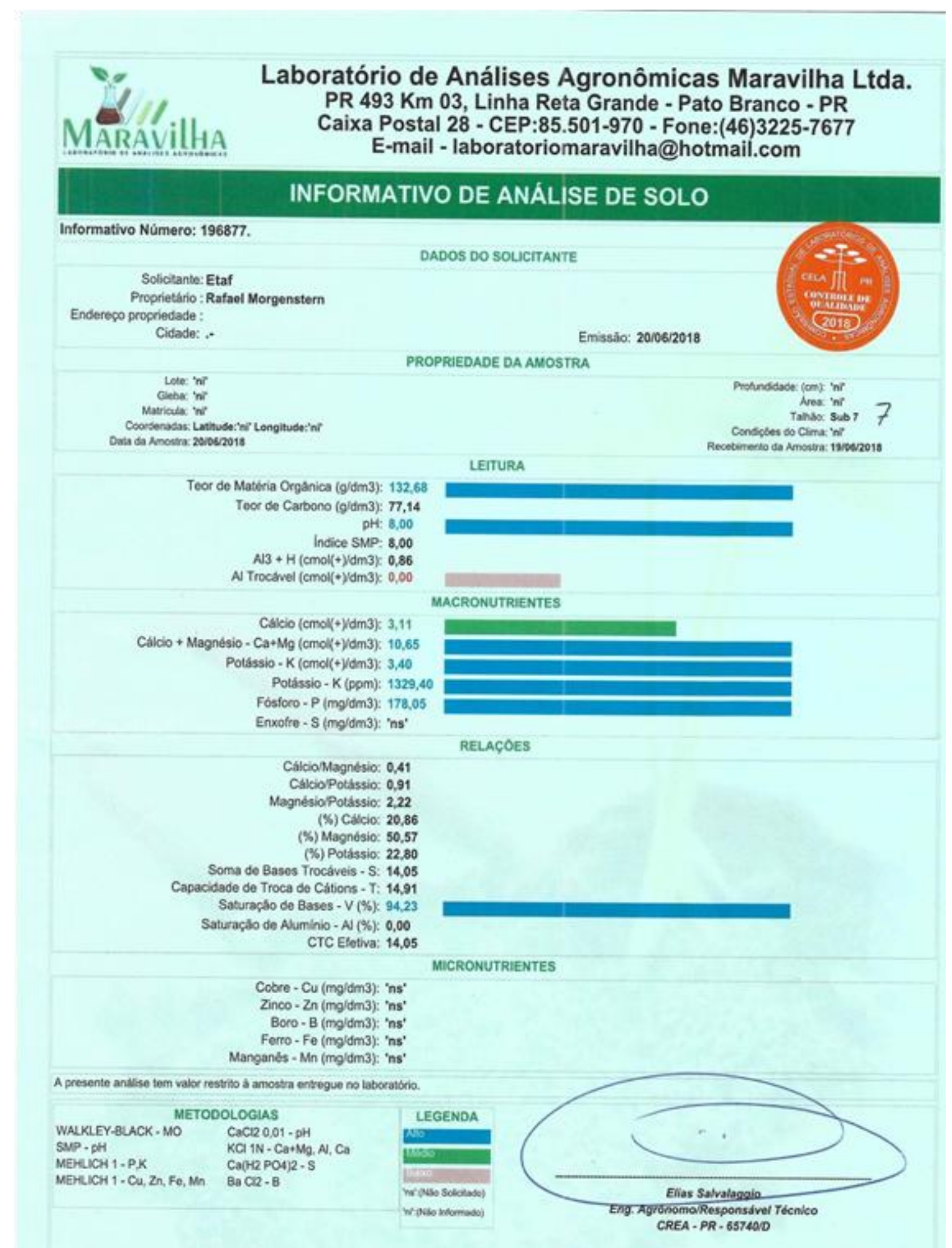

Figure 07 - Analysis of the chemical composition of the substrate based on cane bagasse + bovine manure + poultry manure + sawdust, 2018.

Source: The author 


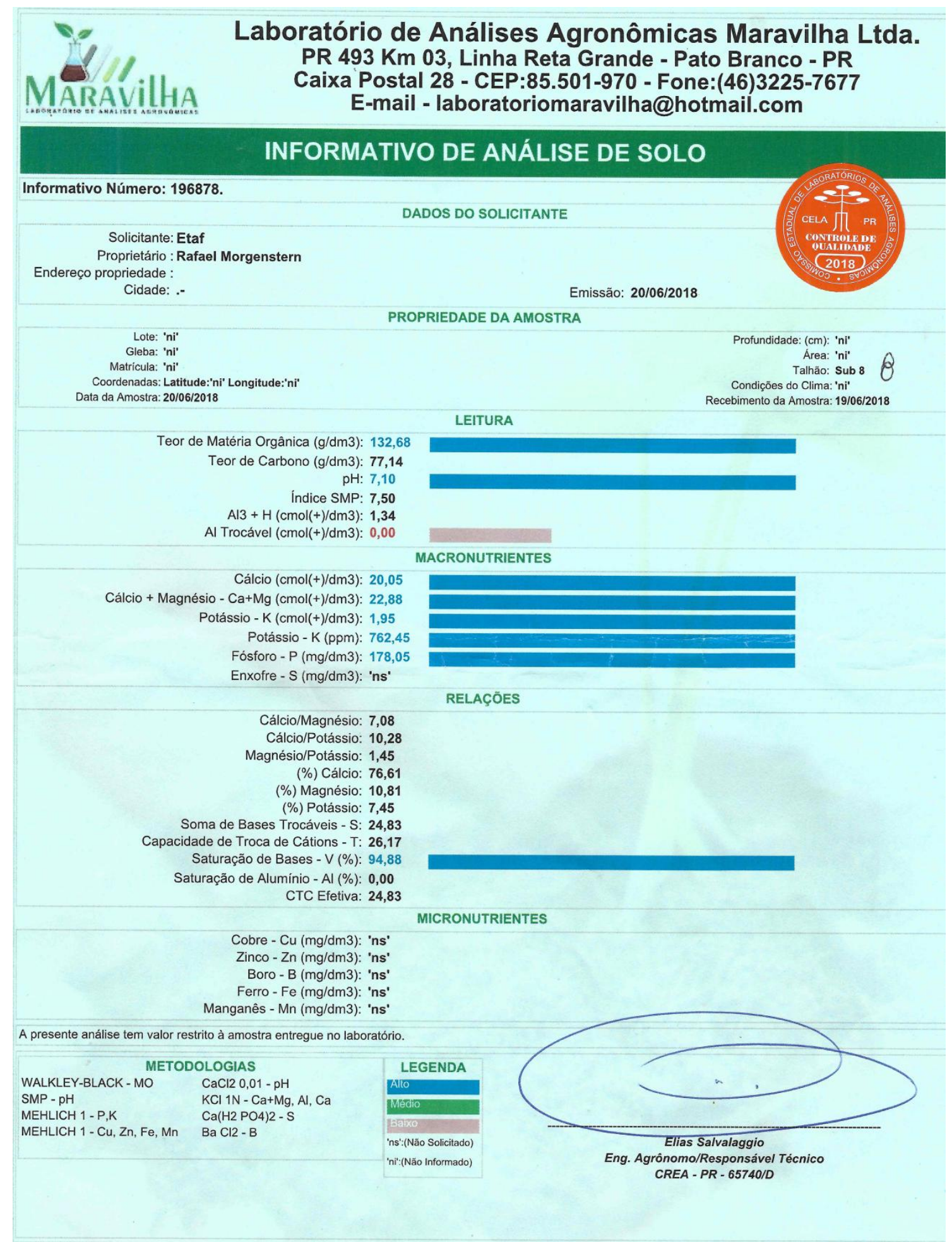

Figure 08 - Analysis of the chemical composition of the substrate based on Witness (Fertile Humus), 2018.

Source: The author

Seeding was performed on April 1, 2018 in $180 \mathrm{ml}$ plastic cups, previously drilled for the drainage of excess water. Crude seeds were used, implanting three seeds per container, after emergence the thinning was performed leaving one seedling per container. Irrigation was carried out with watering can from the sowing with two irrigation shifts a day, with water volume varying according to the needs.

Evaluation of the experiment was performed 60 days after emergence. The variables evaluated were aerial part size, root length, diameter of the plant colon, number of leaves per plant, green mass of the aerial space, green root mass and total green mass of the plant.

To obtain the plant size with the aid of a scale, the distance between the plant collar and the greater apical part was measured. The root length was obtained by measuring the distance between the collar of the plant and the apical region of the larger root, 
Citation: Francielli Geremia et al., Alternative Substrates in the Development of Little Beak Pepper Sprouts. Australian Journal of Basic and Applied Sciences, 13(6): 51-61. DOI: 10.22587/ajbas.2019.13.6.6

data were expressed in centimeters. The diameter of the plant collar was measured with the aid of a digital caliper, the data being expressed in millimeters.

The number of leaves was accounted through counting, considering leaves as final leaves those that were fully expanded. In order to obtain the green mass of aerial part, green root mass and total green mass of the plant, the root system of all the plants were previously washed in running water, then with the aid of a stylus a cut was made in the lap of the plant, separating the root system of the plant area part. Then, the electronic weighing was performed separately to obtain the mass considering four dig its after the comma.x

The data were submitted to the normality test of Lilliefors. After analyzing the variance by the F test $(\alpha 0.05)$, if significant were submitted to the Duncan test $(\alpha 0.05)$. WINSTAT ${ }^{\circledR}$ computing application (MACHADO and CONCEIÇÃO, 2002).

\section{RESULTS AND DISCUSSION}

From the data obtained in the experiment, the analysis of variance was performed, which were significant.

When analyzed the plant size and the length of the root system, the plants cultivated in substrate based on pine bark + bovine manure presented a better development and differed statistically in relation to the other treatments (Table 1)

Such result may be related to the type of organic material used in the substrate composition. Bovine debris presents high amounts of macro and micronutrients essential for the early development of plants.

Table 1: Size of the aerial part (TPA) $(\mathrm{cm})$ and length of root $(\mathrm{CR})(\mathrm{cm})$ of little beak pepper (Capsicum Chinese) grown on different substrates, Dois Vizinhos - PR, 2018.

\begin{tabular}{|c|c|c|}
\hline Types of Substrates & TPA & CR \\
\hline Pine bark + poultry manure & $3,00 \mathrm{~d}$ & $3,70 \mathrm{c}$ \\
\hline Pine bark + bovine manure & $17,05 \mathrm{a}$ & 13,02 \\
\hline Sawdust + poultry manure & $2,95 \mathrm{~d}$ & $3,10 \mathrm{c}$ \\
\hline Sawdust + bovine manure & $3,37 \mathrm{~d}$ & $3,45 \mathrm{c}$ \\
\hline Cane bagasse + poultry manure & $4,05 \mathrm{c}$ & $3,90 \mathrm{c}$ \\
\hline Cane bagasse + bovine manure & $4,12 \mathrm{c}$ & $3,45 \mathrm{c}$ \\
\hline Cane bagasse + bovine manure + poultry manure + sawdust & $4,02 \mathrm{c}$ & $3,50 \mathrm{c}$ \\
\hline Witness (Fertile Humus) & $6,40 \mathrm{~b}$ & $10,50 \mathrm{~b}$ \\
\hline CV $(\%)$ & 6,42 & 10,83 \\
\hline
\end{tabular}

*Averages followed by the same letter do not differ by Duncan Test (0.05).

For the variables number of leaves and diameter of the stem neck (Table 2), it can be seen that the plants cultivated in substrate based on pine bark + bovine manure presented superior results in relation to the other treatments. In this way, we observed a mean of $4.75 \mathrm{~mm}$ of colonic diameter and a mean of 7.5 leaves per plants presenting statistical superiority in relation to the other treatments. These results come to be assimilated to the work done by Silva et al. (2004), where there is a high potential for development of small pepper seedlings when submitted to organic soil substrate and bovine manure.

For Cunha et al. (2005), when formulating a substrate for seedling production it must be taken into account the most diverse factors, so that it will provide ideal elements for its development. According to laboratory analysis, the substrate based on pine bark + bovine manure presented high levels of nutrients together with good physical characteristics of the substrate justifies the excellent results obtained.

Table 2: Diameter of the plant neck (DCP) (mm) and number of leaves (NF) per plant of Bunch pepper (Capsicum Chinese) cultivated in different substrates. Dois Vizinhos - PR, 2018.

\begin{tabular}{|c|c|c|}
\hline Types of Substrates & TPA & CR \\
\hline Pine bark + poultry manure & $1,80 \mathrm{~d}$ & $2,67 \mathrm{c}$ \\
\hline Pine bark + bovine manure & $4,75 \mathrm{a}$ & $7,50 \mathrm{a}$ \\
\hline Sawdust + poultry manure & $1,65 \mathrm{~d}$ & $2,40 \mathrm{e}$ \\
\hline Sawdust + bovine manure & $1,90 \mathrm{~cd}$ & $2,92 \mathrm{e}$ \\
\hline Cane bagasse + poultry manure & $1,95 \mathrm{~cd}$ & $3,7 \mathrm{~d}$ \\
\hline Cane bagasse + bovine manure & $2,12 \mathrm{c}$ & $4,27 \mathrm{c}$ \\
\hline Cane bagasse + bovine manure + poultry manure + sawdust & $1,97 \mathrm{~cd}$ & $4,05 \mathrm{~cd}$ \\
\hline Witness (Fertile Humus) & $3,06 \mathrm{~b}$ & $5,25 \mathrm{~b}$ \\
\hline CV (\%) & 10,62 & 8,80 \\
\hline
\end{tabular}

*Averages followed by the same letter do not differ by Duncan Test (0.05).

Observing the productive potential of aerial green mass in all types of substrates exposed in (Table 3), we noticed that the treatment that excelled from the others obtaining the best average was the one composed of pine bark + bovine manure. When evaluating the root green mass, we noticed that the plants cultivated in the substrate the base of pine bark + bovine manure obtained the best average 2,049 standing out statistically in relation to the treatments.

Regarding the total green mass of the plant, the substrate composed of pine bark + bovine manure was also the treatment that best stood out, followed by the control that was different from the others (Table 3). 
Citation: Francielli Geremia et al., Alternative Substrates in the Development of Little Beak Pepper Sprouts. Australian Journal of Basic and Applied Sciences, 13(6): 51-61. DOI: 10.22587/ajbas.2019.13.6.6

According to Cunha et al. (2006), compounds with slower release of nutrients favor the development of seedlings in the most diverse variables observed, in addition to having a more uniform availability of nutrients and for a longer period they have a good porosity and capacity of retention of moisture available to the plants, as can be observed on substrates composed of bovine manure, the result was similar because they presented a great part of the characteristics required by the culture.

Table 3 - Aerial green mass (MVPA) (g), green root mass (MVR) (g) and total green plant mass (MVTP) (g) of little beak pepper (Capsicum Chinese) cultivated on different substrates, Dois Vizinhos - PR, 2018.

\begin{tabular}{|c|c|c|c|}
\hline Types of Substrates & MVPA & MVR & MVTP \\
\hline Pine bark + poultry manure & $0,733 \mathrm{~d}$ & $0,366 \mathrm{~d}$ & $1,1 \mathrm{~d}$ \\
\hline Pine bark + bovine manure & $4,09)^{*}$ & $2,049 \mathrm{a}$ & $6,15 \mathrm{a}$ \\
\hline Sawdust + poultry manure & $0,799 \mathrm{~cd}$ & $0,399 \mathrm{~cd}$ & $1,2 \mathrm{~cd}$ \\
\hline Sawdust + bovine manure & $0,849 \mathrm{~cd}$ & $0,424 \mathrm{~cd}$ & $1,275 \mathrm{~cd}$ \\
\hline Cane bagasse + poultry manure & $0,916 \mathrm{c}$ & $0,458 \mathrm{~cd}$ & $1,375 \mathrm{~cd}$ \\
\hline Cane bagasse + bovine manure & $0,933 \mathrm{c}$ & $0,466 \mathrm{c}$ & $1,4 \mathrm{c}$ \\
\hline Cane bagasse + bovine manure + poultry manure + sawdust & $0,932 \mathrm{c}$ & $0,466 \mathrm{c}$ & $1,4 \mathrm{c}$ \\
\hline Witness (Fertile Humus) & $2,033 \mathrm{~b}$ & $1,011 \mathrm{~b}$ & $3,033 \mathrm{~b}$ \\
\hline CV (\%) & 8,14 & 8,43 & 8,42 \\
\hline
\end{tabular}

*Averages followed by the same letter do not differ by Duncan Test (0.05).

As shown in the data presented in the tables (1,2 and 3) the treatment that stood out most among the analyzed variables was the treatment composed of pine bark + bovine manure. Based on the nutritional requirements of the little beak pepper (Capsicum chinese) culture, it is perceived that the bovine manure had this efficiency due to the nitrogen content available for the crop and the pine bark component had an efficiency in the availability of calcium, which is also required by the crop.

\section{CONCLUSIONS}

The substrate based on pine bark + bovine manure presented a more satisfactory performance in all analyzed variables. Therefore, it is the most suitable substrate for cultivation of Little Beak Pepper (Capsicum Chinese) under these conditions.

However, the components of the other substrates also present a good efficiency and good nutritional characteristics, being necessary a more specific study regarding the percentages of the components present in each substrate to obtain more specific results that can present satisfactory results for the variables that were evaluated in this work.

\section{FUTURE WORKS}

To evaluate the development of Little Beak Pepper seedlings under saline stress.

\section{REFERENCES}

ALVARES R. C.; REIS, E. F.; PINTO, J. F. N. Genetic divergence in pepper genotypes from southwest Goiás. Ciência e Agrotecnologia, v. 36, p. 498-506, 2012.

COSTA, L. M. et al. Antimicrobial activity of the genus Capsicum. Higiene Alimentar, n.174/175, p.140-145, 2009.

CUNHA, A. M. et al. Efeito de diferentes substratos sobre o desenvolvimento de mudas de Acacia sp. Revista Árvore, ViçosaMG, v.30, n.2, p.207-214, 2006.

CUNHA, A. O. et al. Efeitos de substratos e das dimensões dos recipientes na qualidade das mudas de Tabebuia impetiginosa (Mart. Ex D.C.) Standl. Revista Árvore, Viçosa-MG, v.29, n.4, p.507-516, 2005.

DANTAS, E. R.; ARAÚJO, A. S. Avaliação das propriedades físico-químicas e microbiológicas de pimenta biquinho e sua aplicação em formulações alimentícias. In: XII Congresso de Iniciação Cientifica da Universidade Federal de Campina Grande. Campina Grande, 2015.

EMBRAPA HORTALIÇAS. Perspectivas e potencialidade do mercado para pimentas. Disponível em: < www.emater.go.gov.br/intra/wp-content/uploads/downloads/2011/07/Potencialidade-deMercado-Pimenta.pdf>. Acesso em: fevereiro de 2018.

MACHADO, A., CONCEIÇÃO, A.R. Programa estatístico WinStat - Sistema de Análise Estatístico para Windows - versão 2.0. Pelotas, 2002.

PINTO, C. M. F.; PINTO, C. L. O.; DONZELES, S. M. L. Pimenta Capsicum: propriedades químicas, nutricionais, farmacológicas e medicinais e seu potencial para o agronegócio. Revista Brasileira de Agropecuária Sustentável, v.3, n.2, 2013.

SILVA, R. P. D.; PEIXOTO, J. R.; JUNQUEIRA, N. T. V. Influência de diversos substratos no desenvolvimento de mudas de maracujazeiro azedo (Passiflora edulis Sims f. flavicarpa DEG). Revista Brasileira de Fruticultura, v.23, n.2, p.382-386, 2001.

SILVA, V. F. et al. Efeito do substrato bovino na germinação de pimenta biquinho (Capsicum chinense) irrigado com água residuária. REMOA, v.13, n.5, p.3865-3871, 2014. 